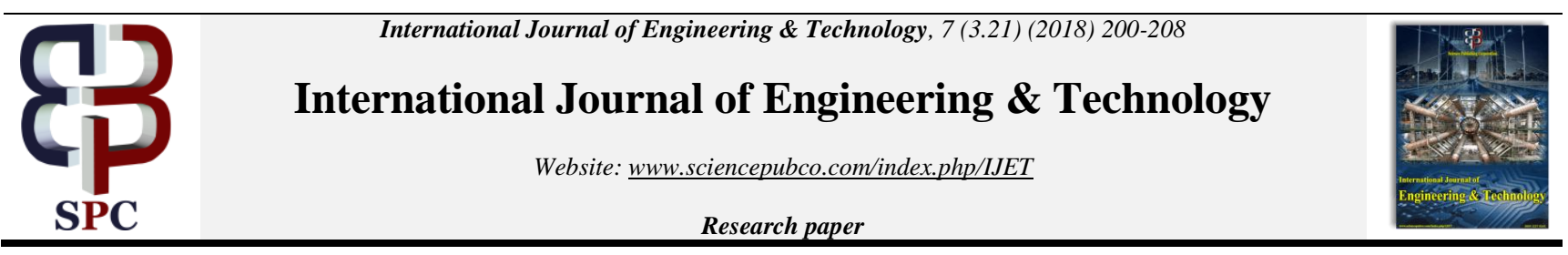

\title{
Managing Tax Dispute Due to IFRS-16 on the Retrofits Implementation in Indonesia
}

\author{
Ismiriai Nasip $^{1}$, Eka Sudarmaji ${ }^{2}$ \\ ${ }^{1}$ University of Bina Nusantara \\ ${ }^{2}$ University of Pancasila \\ *Corresponding author E-mail: ismi.nasip@gmail.com
}

\begin{abstract}
The IFRS-16 will shortly be implemented worldwide, where the operating lease is effectively removed, and all operational leases are qualified as debt. The operational lease is a major source and is important for off-balance sheet financing in Indonesia. Therefore, the implementation of IFRS-16 will probably hurt Indonesian business. The contract and/or service level agreements on the retrofits for the energy efficiency product can relieve the business owner from cash flow and new debts. This study established a framework for a critical comparative study; compare and assess the possibility of the retrofit financial practices under the current taxes regime, and the possibility upon IFRS-16 implementation to better understand the favorable measures for retrofit practitioners and future customers to handle the disputes. Triangulate the findings of comparative study and questionnaire survey to develop recommendation for the future researchers, practitioners and the government. The result indicates that the benefits of the retrofits financing implementation beat the cost and complexity posed by the enactment of new IFRS standards. Thus, the impact of the IFRS-16 and taxation are being considered as a part of business constraints that should be addressed together and able to manage the disputes over misperception on retrofits aspects with taxes officers.
\end{abstract}

Keywords: IFRS; Retrofits; Tax Implications

\section{Introduction}

There is a growing number of the regulation issued on energyefficiency saving with the aim to promote the conservative energy without a clear framework and clear purpose (1). Changes and development of modern business are increasingly connected and integrated within the current digitization changes, and surely must be followed by the adequate New Public Management regime, that critical for the current and next wave of change (2). In term of Indonesia, the tax rules sometimes took a long time to catch up with the modern business development and even got left behind from others countries that evolved rapidly (3). Therefore, the ability to catch up requires large resources and enormous budget. This situation often results in the misinterpretation that eventually put the taxpayer in an awry situation. For the taxpayer, billions of rupiahs in bribes are certainly smaller comparing to the tax deficiencies and fines that must be paid. In the other cases, extortion of taxpayer also happened when the taxpayer seeks the court as a way out.

Most modern tax systems have to follow tax principles in the modern era, which has a fairness grounds, known and understood, convenient for the taxes payer, and efficient on the cost of the taxation system as well as the subsequent cost for taxpayers (4). Meanwhile, accounting policy has represented the modern business that evolves rapidly and complex, but it is more challenging for Indonesian tax system to be more contemporary because Indonesia is one of the countries that have different recording system between taxation and accounting (5). Hence, Indonesian tax systems should be periodically repaired, strengthened, and the outdat- ed regulations should be removed. Tax incentives to promote the business, for example, investment in energy efficiency saving, needs to be designed as the aim of the competitive tax legislation (4).

More recently, the International Accounting Standards Board ("IASB") has developed a new lease standard; it is IFRS-16 that replaced IAS-17 on leasing and it will be applied starting on the 1st of January $2019(6,7)$. However, for those companies who have already implemented IFRS-15, they may choose to start implementing earlier. IASB and Financial Accounting Standard Board ("FASB") have reached the same conclusion, where accounting for capital lease must be reported in the balance sheet (7) The issuance of IFRS-16 on capital lease and possibility of Indonesia following the changes will increase the gap between capital lease aspects in term of taxation and accounting. The possibility of the diverse interpretation of an object will increase. The greater the diverse interpretation, the greater the risk of doing business in Indonesia is because the possibility of the tax official to seek opportunities and create a tax case for the taxpayer and even to do corruption is possibly higher.

Economic consequences will obviously arise as it will change the financial statements and the key accounting ratios (8-10). Every company are facing the same consequences, including Indonesian companies, hence they need to mimic the impacts of the IFRS implementation. The formal or informal contracts may be affected, as well as the impact on taxes consequences as the Indonesian government would change or made an adjustment on the lease tax legislation due to the IFRS implementation. However, the IFRS impact on Indonesian taxation is only on the tax that is not final, while the final tax has no effect at all. Therefore, taxpayers are required to maintain two financial reporting that are applicable for 
tax system and for the accounting system. Thus, the implementation of IFRS in Indonesia is more for the recording process and to reduce the compliance cost that may occur (11).

In the energy-efficiency sector, the implementation of the retrofits financing system will be affected by the implementation of IFRS16 (12), hence, in Indonesia the possibility of the diverse interpretation of a retrofits financing system will probably occur since the object of the taxation, as well as the accounting practices, are new in this area. Investment in the energy-efficiency product is an effective way to reduce the energy consumption(13), increase the comfort room, and most importantly reduce the electricity cost However, the cost of these energy-efficiency products is not inexpensive. Therefore, an agreement with financing through energy saving is a unique financial mechanism, which in many ways is positioned to reduce the upfront costs by exchanging performance contracts or services contracts, namely retrofits $(12,14-16)$. Financing program, through energy efficiency agreement, can utilize customer's utility costs to compensate the investment in energyefficiency product. Retrofits mechanism allows the customer to pay the investment (energy-efficiency products) through utility cost saving, where payment can be done monthly.

Retrofits financing through the energy efficiency is worth considering, especially in public sector or private sector concerning the investment in energy-efficiency product rather than another financing mechanism \{Brown, 2009 \#33\}. Retrofits program seems more difficult compared to another general financing program, it requires long-term commitment, financial resource, human resource, and in some cases, complicated credit evaluation process(17). Under the IFRS-16, operating lease costs are effectively removed, and it is qualified as debt. The investment of the energy-efficiency product is treated as investment off-balance sheet, and it has become more important because the companies who will implement the retrofits financing program do not have to add investment or loan. It will not affect the market value of the company, and most importantly it will not disrupt the company's operational cost.

\subsection{Retrofits Financing Program}

In this study, retrofits are defined as a replacement of old equipment with the new equipment and/or build new infrastructure with the intention to increase energy efficiency and to reduce utility cost before the old equipment are damaged or the economic life finished(12, 14-16). With this definition, retrofits program will involve investment, and the retrofits value will be quantified by the investment payback period $(18,19)$. The payback period will be determined by the value of the investment, the energy cost, and the operational hours of the equipment\{Fuller, 1996 \#3;Mearig, $1999 \# 51\}$. Currently, the new technology forces energyefficiency products tend to be cheaper, while according to the Indonesian Central Bureau of Statistic (2016), the trend of the electricity cost in Indonesia continue to increase, therefore, it is estimated that the retrofits financing program will grow in the future.

This study investigated the retrofits financial program on one of the energy-efficiency products, i.e. LED Lamps. One of the ways to achieve energy saving is by replacing the conventional lamps to LED Lamps. Figure 1. below shows that the consumption of energy by LED lamps is 4.5 times lower than the conventional lamps, and have 1.5 times longer lifetime (20-22). The payback period is also affected either by the increase in the operational hours or by the increase of the electricity cost-per-watt, that is issued by the Power Company (Perusahaan Listrik Negara - PLN). The smaller the payback period is the more profitable and low risk the retrofits financing system is. The example comparison calculation between LED lamps and conventional lamps in shown in Figure 1 below.

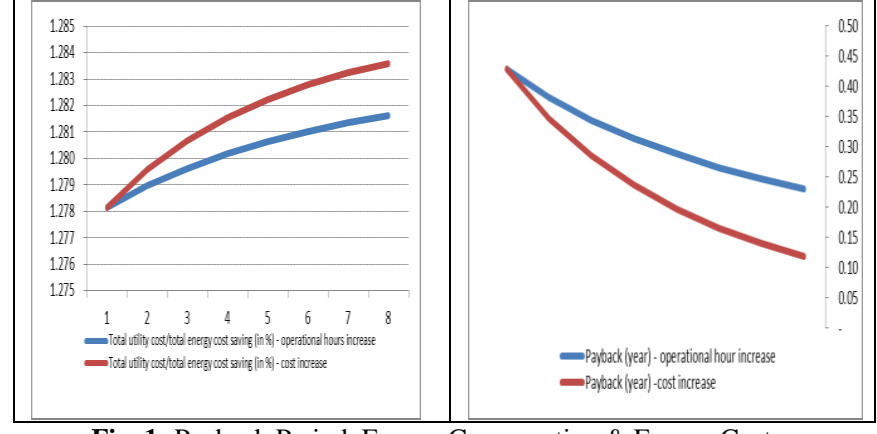

Fig. 1: Payback Period, Energy Consumption \& Energy Cost

Retrofits financing model has both the Energy Saving Performance Contract ("ESPC') and the Energy Saving Agreement ("ESA") that were introduced by The World Economic Forum, and they become the best available options for new and existing energy efficiency finance mechanisms. In the event that a customer cannot fulfill the payment of the service contract, the retrofits provider can take back the equipment that was already installed, and the customer makes payment to the retrofits provider from the energy cost saving. Some analyst believes that ESA \& ESPC can be categorized as a service agreement and an off-balance sheet operating expense.

Beyond January 2019, Retrofits provider would stop offering customers an off-balance sheet leasing solution, consequently, customers need to disclose the assets on their balance sheet, adding debt and increasing the Debt to Equity Ratio $(6,10,23)$. Using the case-study analysis as per Figure 2, the flow of obligation, rights, and the organization that is involved in the retrofits financing system is illustrated, either through ESPC or ESA. Based on Figure 2, the financing ESPC and ESA project scheme can go through service contract agreement and leasing agreement. The ESA's transaction is basically based on the income for the service contract; hence it has no effect due to the IFRS-16 implementation since the IFRS-16 will not change the accounting treatment for the service. Both the leasing and the service contracts are often combined in one agreement and the amount related to the service contract is not required to be reported on the balance sheet. IFRS-16 is only implemented on the operation leasing or leasing components (24). ESPC and ESA can also be defined as leasing components due to 1) the ESPC and ESA dependence on the provision of the certain assets, and 2) ESPC and ESA provide the rights to control the utilization of the certain assets in a certain period of time.

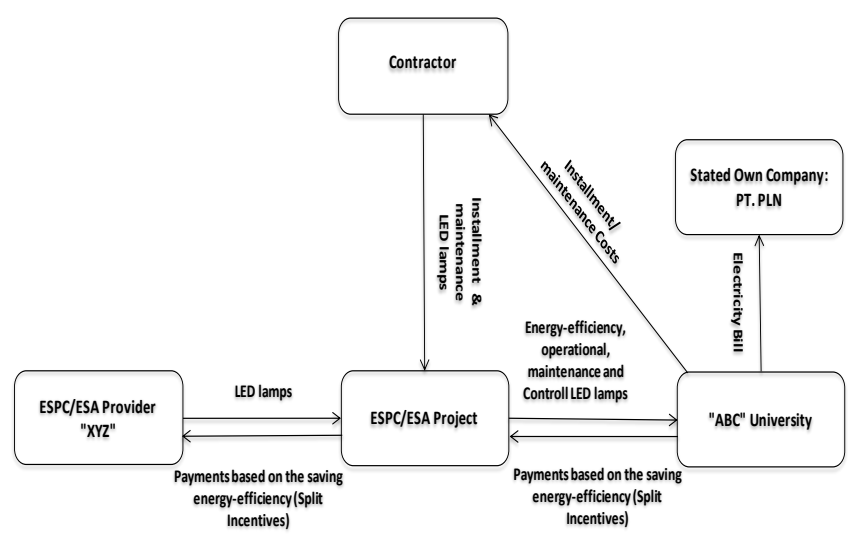

Fig. 2: ESPC and ESA scheme, modified from source (Leventis, Fadrhonc, Kramer, \& Goldman, 2016)

\section{Literature Review}

Positive Accounting Theory is an accounting framework that is applied in this study to explain the characteristics of the retrofits business. From the economic perspective, changes in the accounting can affect the financial situation of the company(25). Econom- 
ic consequences appear when the changes of the information that is reported will affect the cash flow of the company (26). These changing standards might cause unwanted changes in the wealth redistribution between different stakeholders in the retrofits business or Principal Agency problem, $(13,27)$. According to Watts \& Zimmerman (28), three factors that explain the manager's motivation to be willing to follow the changing standards or to choose certain accounting standards are: 1) managers have the incentive to use different accounting methods to avoid problems (for example, reducing profit) so that it will not attract attention, 2) companies with higher loan ratio might choose the accounting standards that increase profit and avoid loan, 3) managers tend to maximize their benefits through compensations that connect to the accounting.

Implications of changing the new accounting standard IFRS-16 might have a big effect towards the loan agreement, capital ratio, compliance cost, worker compensation benchmark, and IT system $(9,10,23,29)$.Cornaggia et al., (30) found that the conventional loan ratio is significantly negative (approximately $1 \%$ ) on operation lease that has the characteristics of the off-balance sheet, and will disappear under the IFRS-16. Whereas operation lease is empirically a significant factor in the company's capital structural right now(30). Cornaggia et al (30) also found that the changes of IFRS-16 have an effect towards the Return on Assets (ROA) maximally. One of the main considerations of the use of operating lease is that off-balance sheet is healthy for the financial strength. As an additional record, the operating lease will also significantly increase the financial ratio such as "loan to capital - D/E", "return on assets (ROA)", interest cost and rental cost. While capital leased can result in tax saving. Wong and Joshi confirmed that the financial statement would change significantly when the IFRS-16 towards all operation lease is capitalized, whereas the asset and liabilities are recorded(10). Their studies also found that operating lease capitalization will have an effect on the number that is reported in the balance sheet and profit-loss account, and it results in significant changes to the profitability ratio and debt ratio. Operation lease is the most important source for the financing offbalance sheet (25). The Morning Ledger magazine (CFO Journal, 11 August 2014) predicted that the total operating lease as the offbalance sheet is approximate $\$ 2$ billion. Mellado \& Part \{Mellado, 2016 \#44\} also found that companies that have investment-grade "BBB" tend to use operation lease.

Meanwhile, Cornaggia et al (30) and (31) found the empirical proof that shows the positive correlation between capital lease and company's loan. Schallheim et al. (31) stated that there is a positive correlation between companies that have big credit capacity and the easiness to use loan with operation lease. The stock analyst reported that the changes in IFRS-16 do not affect the judgment towards their management credibility. However, the analyst also reported that if the management can provide operation lease reconciliation, it will increase their appraisal towards the management credibility (32).

\subsection{Leasing Provisions on PSAK (IFRS Indonesian Chapter)}

The advent of PSAK 73; IFRS Indonesian chapter cannot be separated from global developments, especially those that occur in the capital markets and the development of information technology. The Institute of Indonesia Chartered Accountants (DSAK IAI) has ratified the Exposure Draft (ED) PSAK No. 73 on 26th of April, 2017. Indonesia, along with almost all the countries in the world, has required their financial statements to use IFRS. IFRS is a standard that governs how companies prepare financial statements in accordance with the standards accepted by the global community. If Indonesia adopts IFRS, it means that Indonesia will follow the accounting standards and financial reporting standards accepted by the international society and can be understood and accepted by the world $(33,34)$. The financial accounting standards in Indonesia that are prepared by the Indonesian Financial Accounting Standards Board ("DSAK") should be able to follow the develop- ment of the economy and the business world, thus DSAK must follow the development of international accounting standards issued by the IASB (35).

The (36) stated that leases establish the principles of recognition, measurement, presentation, and disclosure of leases by introducing a single accounting model specifically for lessees. Lessees are required to recognize right-of-use assets and lease liabilities. There are two optional exclusions in the recognition of the lease assets and liabilities, namely: (i) short-term lease and (ii) lease with low-value underlying assets. Under DE-PSAK73: Leases substantially carry the rental accounting requirements, which previously stated under PSAK No. 30: "Lease for lessors". Thus, the lessor continues to classify the lease as operating lease or finance lease and record both types of leases differently. However, additional disclosures on the risk exposure were required. With the enactment of PSAK73, it automatically revoke: (a) PSAK 30: "Leases for lessee"; (B) \{Ikatan Akuntan, 2014 \#52\}: Determining Whether an Agreement Contains a Lease; (C) (37): OperationIncentive Rent; (D)(38): Evaluating the Substance of Transactions Involving a Legal Form of Lease; and (e) (39) 5: Land Rights. Meanwhile, under (40): "lease for lessor", the lease is about operation lease that acts off-balance sheet set out in paragraph 8 , meanwhile the leasing is classified as a capital lease financing if it transfers substantially all the risks and benefits connected to ownership. However, the leasing is classified as operating lease if it acts otherwise. Paragraph 10 stated that classification of the leasing as capital lease or operating lease is based on the substance of the transaction rather than the form of the contract (Ikatan Akuntan Indonesia). An operating lease in the IFRS-16 is defined as a contract addressed to the lessee, the rights to use assets for a specific range of time. A company assesses the contract contains capital lease is based on whether the customer has the rights to control the use of assets for a period of time. The requirements related to the definition of rent in the IFRS-16 changed from IAS 17.

\subsection{Impact of Changes in IFRS-16}

"In my book, if it looks like a duck, swims like a duck, and quacks like a duck, then it probably is a duck. So is the case with debt - leasing or otherwise." - Hans Hoogervorst, Chairman, IASB, November 2012.

That is roughly how the analogous leasing rental fee has been applied in accordance with the existing accounting standards all these time. Hoogervorst (41) is very concerned about the risks that may arise from the practice of operating lease and treatment of off-balance sheet (41).

IFRS-16 standard does not significantly alter the accounting system for capital lease in the lessor situation. This happened because the IASB decided to continue the accounting model of capital lease for lessor in accordance with IAS-17 standard. However, IFRS-16 requires the lessor to provide some additional information disclosures to enable users of financial statements to evaluate the uncertainty of the cash flows associated with the lessor's activity (24). It can be said that the substantial changes occur for the capital lease for lessee position (www.iasplus.com): 1) all the capital lease contract with limited exception, must be reported to the balance sheet account, 2) a new definition of the capital lease contract, 3) capital lease contracts and service contracts must be separated, 4) a reassessment of the capital lease contractual obligations, and 5) ratings of capital lease contract period.

In the financial statements, the impact on the balance sheets of the lessee happens to the asset account and debt accounts related to the cost of operating leases that were previously not recognized in the balance sheet accounts as shown in Figure 2. In addition, the straight-line cost method, which was previously recognized for operating lease will be replaced by depreciation costs (which are usually based on the life time of the asset) and interest expense (which will decrease during the lease period as a payment made). 


\subsection{Leasing in Taxation System}

A difference of capital lease between accounting and tax is the depreciation that is disallowed to the lessor and lessee. The common logic used by the tax is due to asset ownership (legal documents) that is still owned by the lessor. The difference in the transactions recording causes consequences in tax obedience because it pushes the tax evasion. The most common practice is the changing of leasing transaction to credit sale transaction so that the lessor avoids paying taxes and the seller only records interest income. The differences in the capital lease put pressure to the capital lease practices in Indonesia.

On the other hand, the pressure to increase tax receipts forced the tax authorities to increase the pressure on taxpayers. When the calculations are different, many taxpayers today seek the court in resolving the tax dispute. There are three factors that cause the potential tax disputes: 1) differences in interpretation of the provisions on the tax amount; 2) limited ability of the tax authorities; 3 ) lack of coordination in the implementation of tax collection between the taxpayer and the tax authority. The first and second factors are the most dominant factors that led to a tax dispute. The ability of the tax authorities in understanding today's modern business operations includes the ability to understand the tax laws that may have been related to the business operations is a fundamental issue in the Indonesian Tax Office.

Based on the empirical research finding, (42) found that the level of taxpayer's moral in Indonesia has not grown yet and it happened because of the external pressure (enforced tax compliance), i.e. by a number of tax penalties. Meanwhile, Sumartaya \& Hafidiah (43) found that the level of tax awareness and tax morale significantly determine the level of tax evasion in Indonesia. The difference in the moral level of the taxpayers in Indonesia is also determined by the different level of education and age (44).

If the new regulations are issued following the business sector development that is constantly evolving, it would surely produce negative effects and create new problems. Many new regulations are issued without a base and a very good reason, where understanding utilitarianism or cost-benefit and the impact for many communities have not been considered from the beginning. Increased regulation burdens many companies and even the economy especially when the national economy is in crisis. Thus, the costs incurred because of new regulations, without a doubt, are much higher than the benefits they get. Again, the cost-benefit analysis should be done, because if it is not, there will be a cumulative charge buildup that occurs due to the negative effects of the new regulations.

A complication on new regulations also causes the development of 'underground economy' or 'shadow economy'. The underground economy is the production of goods and services, both legal and illegal that is missed from the calculation of Gross Domestic Product (GDP). One of the reasons to do the underground economy activity is to avoid taxes. This underground economy causes the ratio of tax payments in Indonesia to be small compared to the ratio of tax payments in other countries. Samuda found that the underground economy activity in Indonesia occurs due to the severity of the tax burden in Indonesia.

Tatariyanto (45) found that there is strong evidence that the underground economy increased significantly in response to changes in tax policy and because of the rising level of unemployment. While on the other hand, the increase in awareness of taxpayers to pay and submit their tax returns will minimize the underground economy activity in Indonesia. In his research findings, the size of the underground economy in Indonesia between 2000 and 2008 was approximately $20 \%$ of GDP. He found that the underground economy substantially reduces tax revenues in Indonesia. Lost tax revenue is expected to have an average of $3.8 \%$ of national GDP during the period of observation. Many empirical studies have found that the underground economy in a country is influenced by various factors, tax and social security; the complexity of the tax system; the cost of business formalization rates; the effectiveness of tax administration; and attitudes toward government and government expenditure (46).

\section{Methodology/Materials}

The practice of retrofits off-balance sheet financing is new and very complicated because it is associated with a variety of risks that must be considered. To examine the complexity, a mixture analysis of qualitative and quantitative is used to explore financing activities off-balance sheet of the current business risk and from the perspective of modern finance. This study includes a semistructured questionnaire, interviews, and document analysis, adhering to the principles of Grounded Theory methodology (47-49). Some of the respondents who participated in this study are involved in the current retrofits project activities: provider "XYZ" and " $\mathrm{ABC}$ " University, with specialized knowledge of the current technology, new energy-efficiency product, technical experts, marketing experts, accounting experts and financial experts. The respondents from ESPC and ESA provider have a combined experience of over 20 years in the lighting industry, in the marketing industry, and in the financial industry.

To understand the current practice situation, the author used a conceptual framework originated by (50) as a primary conception or model of what is out there and of what is going on with the retrofits financing. There is not much-known situation at hand right now, no-similar problem and research have been found. Hence the author hopes to able to describe the characteristics of the transactions. Below is the proposition as a part of our conceptual framework and become a key task in designing this study.

Proposition 1: Managers of "ABC" University have the incentives to implement the retrofits program. Even though "ABC" University (lessee) does not completely understand about the retrofits project for energy efficiency. Plus, they also do not understand the impact of the latest changes in accounting standards IFRS-16 on the capital lease, the impact on accounting system and taxation system. Fortunately, they believed that they are able to manage the disputes over miss perception on retrofits aspects.

Proposition 2: The retrofits project is very feasible to be implemented by "ABC" University. The financial analysis in terms of the rate of return on investment and all the investment risk exists and over-rides the obstacle.

\subsection{Data Collection \& Analysis}

Due to the lack of information in the public domain, a series of a semi-structured questionnaire and interviews conducted with the top-level people, such as the owners and general managers who are responsible for managing the retrofits project. Grounded Theory is used to explore what lies behind the phenomena, the data is systematically collected and analyzed through a series of the research process $(47,48)$. In this method, data collection, analysis, and the theory were eventually interconnected with each other. This theory focuses on the need to gather information on the incident and the facts. Tomkins and Groves show that collecting information using case studies and interviews fulfill the principles of 'directly and without constraints' (51). The interview process helps obtained the information directly from the company's owner, corporate executives and general managers in the projects involved. Participants were chosen carefully to reflect the actual incident.

Secondary data were obtained from industry data, and project documents used to better understand the lighting industry and energy-saving technology, determine the key points that should be addressed during the interview and observation. This first step allows the authors to be able to identify the key dimensions of the questionnaire given, covering all aspects of the industry, the technical aspects, and managerial aspects. Interviews were conducted between the months of November 2016 until January 2017, with the duration between twenty minutes to sixty minutes. Each participant was asked to comment on the following topics: 1) their defi- 
nition of energy-efficiency product; 2) The technological concept of energy efficiency and energy-efficient appliances: its origin; 3) the implementation or execution of energy-efficiency product and how it is related to the overall retrofits strategies; 4) the key success factors of the retrofits strategy; 5) the role of energy efficiency in a sustainable retrofits strategy.

\section{Results and Findings}

The author presented the facts of funding off-balance sheet and its relationship with the practice of taxation and accounting in accordance with the accounting standards IFRS-16, and how to incorporate that into companies' balance sheets, finance strategy, financing models and strategies of the capital lease, as well as alternative financing off-balance sheet. The biggest consequences were how to deal with taxation issues especially when misunderstanding on business and transaction perception occurs between tax offices and taxpayers.

The provider "XYZ" and "ABC" University are using basic financial analysis tools to check the value, risk and liquidity impact on investment opportunities with its resources. To compete successfully with other businesses, energy-efficiency projects need to be evaluated on the same basis with others. Basic financial measurements with the basic analysis tool used in this retrofit project. The provider "XYZ" uses financial analysis to identify whether an investment reaches the required level of profitability while maintaining investment and liquidity of customers.

To assess the feasibility of the project, the study used the same approaches and guidelines by EPA-Energy Start (52): 1) prepare a cash flow analysis for each option contract, whether the ESPC and ESA contract is doable or not; 2) calculate the IRR for each of these options to determine the level of profit from each option, and take into account the rate of return required (hurdle rate); 3) compare the options and prioritize options by using the NPV; and 4) maximize energy efficiency with which option is most appropriate. Profitability is usually measured by the internal rate of return projects passed the level of investment required (hurdle rate). Cash flow and financial liquidity of the customer is evaluated first, then the rate of return (payback). The hurdle rate is the accepted/rejected criteria for determining whether an investment passes the profitability test. If the IRR is higher than the required rate of return, the project is otherwise profitable investments. The required interest rate is the marginal cost of capital, adjusted for the risk of the project. The higher the cost of capital and risk, the higher the level of profit required. EPA Energy Star recommends using the required rate of return is 20 percent for energy-efficiency investments (52).

\subsection{Case Study of ESPC and ESA Provider "XYZ" and "ABC" University}

For the purpose of this study, the pseudo name for the provider "XYZ" and "ABC" University have been used to protect the secrecy and only for the research's descriptive. The provider "XYZ" is LED lamps distributor, and one of the biggest suppliers of LED lamps for the Jakarta and surrounding market with the average annual number of employees of 60 people. The provider "XYZ" encourages sales of energy-efficiency lamps to " $A B C$ " University. Energy-efficiency appliances and power saver utility costs (energy costs) are the main factors to measure the performance of energyefficiency retrofits project at "ABC" University. The provider "XYZ" computes the feasibility through the performance analysis for both ESPC and ESA contracts based on data provided by "ABC" University. The current investment value (NPV), the rate of return (payback period) and the rate of profit required (hurdle rate) is an analysis tool that is used. The provider "XYZ" periodically reviews the objectives, investment strategy and a desire to expand their market share and customer base.

"ABC" University is a provider of educational services and lectures, with the main source of income that comes from the stu- dents. "ABC" University will use the energy-efficiency product as an attempt to reduce the utility cost and to have some savings (energy costs) with the help from provider "XYZ". "ABC" University conducted a feasibility study under the ESPC retrofits project and ESA contract, used the same data and computation of utility cost savings provided by the provider "XYZ". Both analyzed, checked the facts, estimated the outcome, set the implementation of strategy and analysis on electricity cost savings that occur as well as divide those saving incentives among them.

The findings of the case studies provide new insights into the factors that influence the decision of both parties to adopt and proceed with the retrofits project for energy efficiency. The results showed that the benefits of the retrofits project implementation beat the cost and complexity posed by the enactment of new accounting standards and procedures. However, the authors are aware that there are so many factors that affect the practice of 'offbalance sheet' and the implementation of the retrofits project. Both factors, technology, and administration emerge from this case study analysis also supported the analysis of literature, which significantly affected the participants to adopt the decision and proceed with the retrofits project, while constraints on the project agreed to be addressed together.

Findings from this study suggest that technological factors affecting both participants are significantly greater than a factor administration. Therefore, this study needs to reaffirm about the "proposition 1: the provider "XYZ" and "ABC" University know and understand about the retrofits project and its consequences. While the impact of the latest changes in accounting standards IFRS-16 that exist in the accounting system and taxation is positioned as a part of business constraints should be addressed together".

Since the observation and interview results show that the retrofits benefits outweigh the negatives consequences for being unknown in the changes of new accounting systems IFRS-16 as well as direct impacts to tax payments, and both participants believe that the negotiation will occur to determine the specs, scope of works as well as the incentives attainment from the collaboration project and able to manage the disputes arise between them. Hence, proposition 2: "ABC" University (lessee) and provider "XYZ" understand the benefits of the retrofits project for energy efficiency. They do not understand the impact of the latest changes in accounting standards IFRS-16 on the capital lease, as well as the impact on accounting system and taxation system. They believe that they are able to manage the disputes over misperception on retrofits aspects".

The descriptive analysis type of financing for ESPC and ESA contracts described in Table 1. can be drawn that the ESPC contract in "ABC" University can use the capital lease contract or onbalance sheet financing, where these types of transactions are linked to the payment with new equipment installed. It is also emphasized by the rights option of ownership over the new equipment after the contract is completed. The ownership rights can be ascertained incorporated into the ESPC contract. While the provider "XYZ" has an obligation to continue to provide a guarantee on savings in utility costs over five years (the age of the equipment) started from the new equipment is installed. Problems may arise from the taxation aspects of assets classification of new leased equipment which is not listed in the list of the capital lease criteria as stated in the decision of Indonesia Ministry of Finance No. KMK 1169/KMK.01/1991 article.3(b). Detailed recommendations on the impact of taxation on ESPC contract (capital lease) set forth in the conclusions parts 
Table 1: IFRS-16 Impact on the Business - ESPC Project Solution for "ABC" University

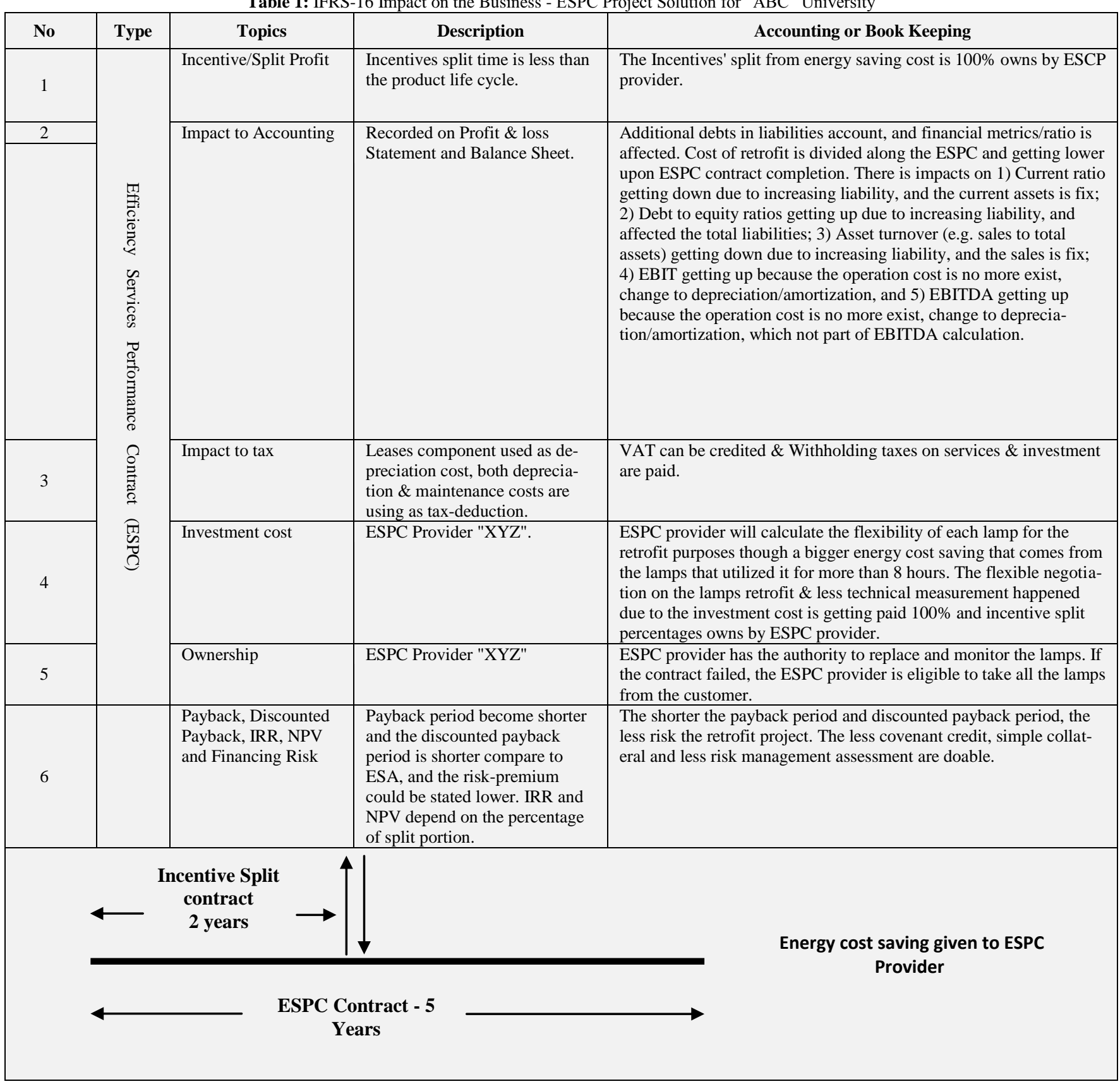

On the other hand, in Table 2. shown that the ESA contracts might be applied at "ABC" University the operating lease or off-balance sheet financing, where these types of transactions are linked to the payment of contract-services of equipment. There is no rights option of ownership granted to "ABC" University, while the provider "XYZ" has an obligation to continue to provide a guarantee on savings in electricity costs for five years in accordance with the service contract. No problems should arise from the taxation aspects since the transaction is classified as normal operation lease transaction.

Table 2: IFRS-16 Impact on the Business - ESA Project Solution for "ABC" University

\begin{tabular}{|c|c|c|c|c|}
\hline No & Type & Topics & De scription & Accounting or Book Keeping \\
\hline 1 & 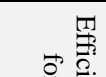 & $\begin{array}{l}\text { Incentive/Split } \\
\text { Profit }\end{array}$ & $\begin{array}{l}\text { Incentives split is equal with the product life } \\
\text { cycle. }\end{array}$ & $\begin{array}{l}\text { Negotiation of Incentives' split based on the ability of energy } \\
\text { cost saving that fulfilled the ESA developer's hurdle rate. }\end{array}$ \\
\hline 2 & 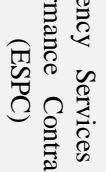 & $\begin{array}{l}\text { Impact to } \\
\text { Accounting }\end{array}$ & $\begin{array}{l}\text { Recorded in the Profit \& loss Statement only, } \\
\text { no record or off-balance-sheet for Balance } \\
\text { Sheet. }\end{array}$ & $\begin{array}{l}\text { No additional debts in liabilities account, and financial met- } \\
\text { rics/ratio is not affected. Cost of retrofit is divided along the } \\
\text { contract \& almost the same amount every month. No impacts } \\
\text { on 1) Current ratio; 2) Debt to equity ratios; 3) Asset turnover } \\
\text { (e.g. sales to total assets); 4) EBIT; and 5) EBITDA. }\end{array}$ \\
\hline 3 & $\underset{\frac{1}{1}}{-9}$ & Impact to tax & $\begin{array}{l}\text { The energy cost (electricity cost) is used as } \\
\text { tax-deduction }\end{array}$ & $\begin{array}{l}\text { VAT \& Withholding taxes on services \& investment are no } \\
\text { available. }\end{array}$ \\
\hline
\end{tabular}




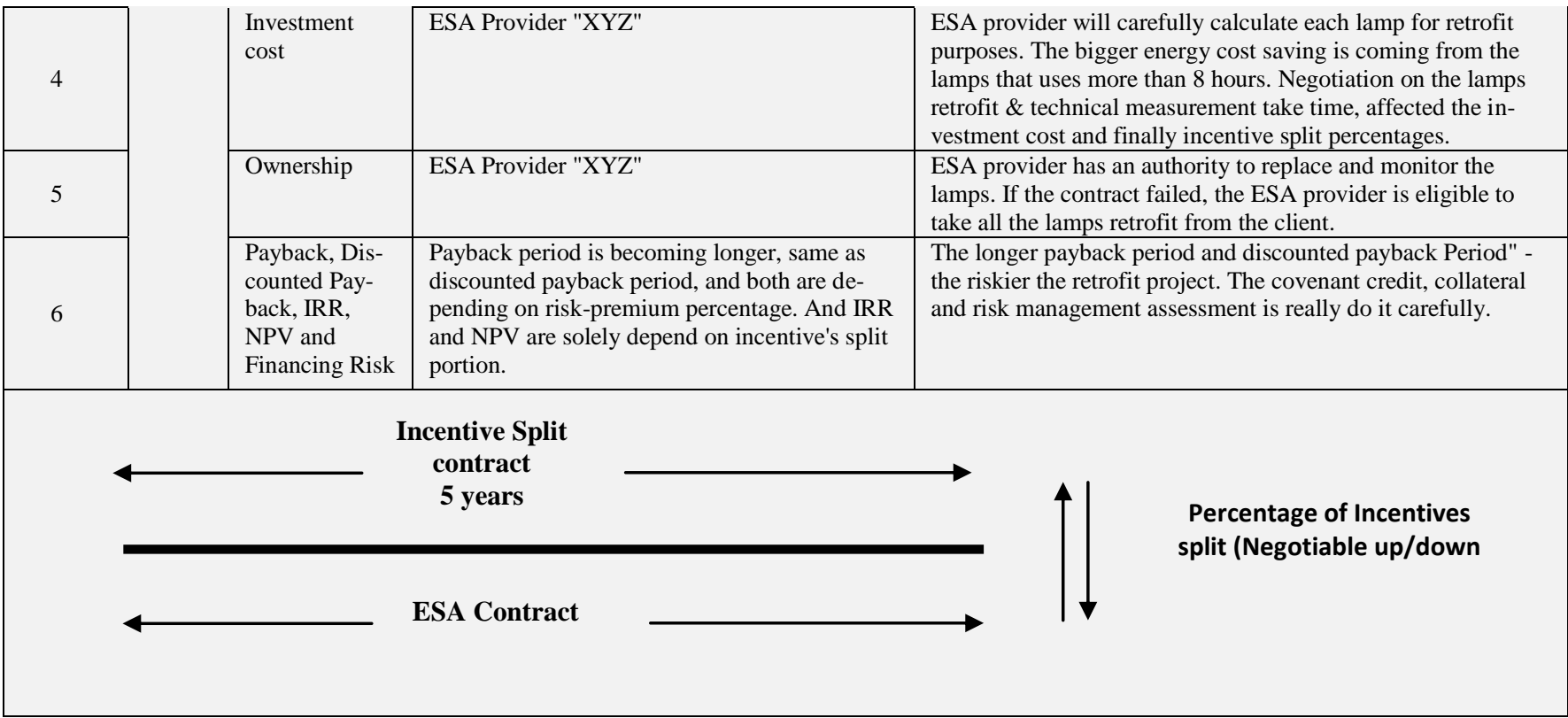

\section{"AB C" University}

Internal Rate of Return Calculation (in million IDR)

Conventional lamps energy costs

LED lamps energy costs

Energy cost saving

Lamps replacement \& maintenance costs

Total energy $\&$ replacement $\cos t \mathrm{~s}$ aving

Less; LED lamps investment

Investment weighted to the project

Original investment costs

Net Cash Flow

\begin{tabular}{|c|c|c|c|c|}
\hline 1st Year & 2nd Year & 3rd Year & 4th Year & 5 Year \\
\hline 2,675 & 2,675 & 2,675 & 2,675 & 2,675 \\
\hline (799) & (799) & (799) & (799) & (799) \\
\hline 1,876 & 1,876 & 1,876 & 1,876 & 1,876 \\
\hline- & - & 396 & - & 396 \\
\hline 1,876 & $\mathbf{1 , 8 7 6}$ & 2,272 & 1,876 & 2,272 \\
\hline$(1,982)$ & - & - & - & - \\
\hline $100 \%$ & - & - & - & - \\
\hline$(1,982)$ & - & - & - & - \\
\hline (106) & 1,876 & 2,272 & 1,876 & 2,272 \\
\hline - & & & & \\
\hline (106) & 1,769 & 4,041 & 5,917 & 8,189 \\
\hline 1.00 & 0.94 & 1.78 & 3.15 & 3.60 \\
\hline - & 1.06 & 1.22 & 0.85 & 1.40 \\
\hline \multicolumn{5}{|c|}{ 1.06 Years } \\
\hline \multicolumn{5}{|l|}{$8.00 \%$} \\
\hline (99) & 1,608 & 1,804 & 1,379 & 1,546 \\
\hline (99) & 1,510 & 3,313 & 4,692 & 6,238 \\
\hline 0.93 & 0.80 & 1.46 & 2.50 & 2.75 \\
\hline 0.07 & 1.20 & 1.54 & 1.50 & 2.25 \\
\hline \multicolumn{5}{|c|}{1.20 Years } \\
\hline \multicolumn{5}{|l|}{6,238} \\
\hline \multicolumn{5}{|l|}{$1642 \%$} \\
\hline 4.15 & & & & \\
\hline
\end{tabular}

Fig. 3: Financial Analysis for ESA Project

Analysis of Cash Flow, NPV, Payback Period and IRR stated in Figure 3. can be concluded that the profitability of this retrofits project has passed the level of investment required (hurdle rate). Cash flow and financial liquidity of customers have a rate of return (payback) that were quite good at 1.06 years without discounted rate and 1.20 years with a discounted rate of deposit interest at eight percent p.a. (8\%) that are commonly used. In the payback period rate of return on the project shows that the risk is a quite low. The NPV shows that total net cash flow generated by the project throughout its five-year life of the project amounted to IDR 6.23 billion, plus this project has the level of profitability of 4.15 on the initial investment cost totaling IDR 1.98 billion. Meanwhile, the IRR exceeds the required interest rate (hurdle rate) of $20 \%$, and it shows that the project is deemed profitable. Therefore, the authors are very confident and confirmed the Proposition 2: that energy-efficiency retrofits project is very feasible to pro- ceed and installed by "ABC" University, in terms of the rate of return on investment and all-risk investments that exist.

\section{Conclusion}

This study helps to understand how both participants in this retrofits projects understand the nature of ESPC and ESA contract and the consequences, their value of the investment, funding models, project performance analysis and accounting \& taxation issues surrounded. The grounded theory would help analyze the issue through semi-structured interviews and observation, in a natural way and in accordance with the existing business processes. The process of grouping based on keywords grouped and given identity (code), in order to identify the financial and non-financial aspects, both short term and long term. In line with grounded theory 
approach, both participants will focus on the processes to achieve the goals and objectives generated. Both participants are using a financial model approach by measuring the performance of the project to ensure it meets the financial aspects as well as the results of the non-financial aspects.

Financial aspects include the estimation of the retrofits profit, the rate of return, the percentage of the value of the energy efficiency should be shared, and investment value of the project is disbursed. The non-financial aspects involved are technically related to the installation of equipment, technology, equipment, and maintenance of equipment or LED lamps. The results of the retrofits projects were being considered as the very benefits by both participants, they were certain about energy-efficient lighting technology, calculation of electricity consumption and savings, and environment-friendly lighting. At the questionnaire and interview, both participants have expressed their intentions about the vision and strategy for retrofits projects that are under ESA contract will be explored further through collaboration between them.

Meanwhile, for income tax purposes in Indonesia, the payments on a capital lease are deducted in the income statement as incurred. Thus, changes of IFRS-16 has no impact on the book keeping for the taxes' lease of both permanent different or the timing different, which have an impact on the corporate income tax. But it is expected that there will be a tax on the accounting consequences of the adoption of IFRS-16, since the cost of operating leases are being capitalized and those liabilities are being recorded on the balance sheet. The changes on some taxes account for the temporary time different will impact on deferred income taxes. Therefore, the IFRS-16 can drive change of tax treatment of operating lease, and the key factors over the standard IFRS-16 for the financial industry are how to treat the government as regulator policy over asset accounts and debt accounts for companies in the financial markets and the capital markets (www.cmawebline .org, January 2017).

In the execution of the ESPC Project, the provider "XYZ" and "ABC" University, referring to an agreement with rights option of capital lease where energy-efficiency lamps can be owned by "ACB" University. Whereas the period of the capital lease on this project tends to be shorter than the provisions based on the assertion in paragraph.8 of the Indonesian Director of General Taxation Circular Letter No. SE-29 / PJ.42 / 1992 dated December 19, 1992, that in terms of capital lease agreements stated shorter or the execution ends in a period shorter than the minimum period required, then the taxation treatment over capital lease will treat as an operating lease.

The ESPC contract that will be implemented at "ABC" University has advantages and disadvantages for both parties, which are:

1) The customer only pays based on energy savings that occur.

2) The customer can apply for off-balance sheet financing (operating lease), under DGT letter No SE-29/PJ.42/1992.

3) The customer does not have the burden of maintenance costs, replacement of lamps that failed, and include the energy savings promised.

4) The provider has an incentive to maximize the savings that can be achieved.

5) The provider can make this project as a 'product-servicesystem', i.e. as a marketing channeling alternative for selling the products.

6) The provider can utilize the maximum rebate on the purchase of products/equipment because the amount is very large.

7) The provider can find the investors on the similar project to reduce the burden of transaction costs.

Moreover, the weaknesses of the implementation of this ESPC retrofits project now are; 1) IFRS-16 have a little room for the providers and the potential customers in determining or moving to a reduction in transaction costs and tax costs; 2) the provider must understand its customers, including the assessment of the credit risk of customers; and 3) the provider acts as the owner of the funds, the investment provider and guarantor of equipment. Offbalance sheet financing is very important for energy efficiency; it can be the key driver for a stronger Indonesian economy. The ESA contract practice in the United States today have shown that energy efficiency saves a lot of costs, reduce waste, improve energy security, and create jobs (53). Authors believe that the Indonesian economy will grow and benefit from the retrofits practices; the regulator, industry and user communities should collaborate. This can minimize the bad consequences of unwanted strict regulations, so that the development of business, the technological products, and modernized services innovation practices will not pose a threat to the safety and health of the national economy.

Limitation of this study is the ability to analyze retrofits project under utilitarianism concept i.e. utility costs and benefits of both sides, both in the retrofits providers as well as from the side of its customers. The study did not discuss any use of energy-efficiency appliances (i.e. appliances that are widely categorized as 'green products'). In many countries, the company's ability to reduce energy and use green products has been awarded, and can be compensated commercially, and can be reported as gains in the company's balance sheet accounts. Another limitation is that the calculation of the retrofits project starts from the issuance of new accounting standards IFRS-16 by the IASB that will still be effective in early 2019. Indonesian DSAK may not adopt the whole accounting standard IFRS-16 recently and tax authority probably will make a significant adjustment. It means that there is a room for Indonesia to consider whether the policy can benefit economically to leasing industries, green-technology business, and other related industries. Therefore, the authors believe, there are many possible variables that are not included in this study, especially the possibility of a lot of things that are specific to the presence or absence of favorable incentives to the retrofits stakeholders involved, or whether there is any aspect of compliance in following the accounting standard and taxation regulations that the author cannot find (hidden), and the authors cannot count or describe quantitatively.

\section{References}

[1] Qian QK, Chan EHW. Government measures needed to promote building energy efficiency (BEE) in China. Facilities. 2010;28(11/12):564-89.

[2] Dunleavy P, Margetts H, Bastow S, Tinkler J. New Public Management Is Dead-Long Live Digital-Era Governance. Journal of Public Administration Research and Theory. 2005;16:467-94.

[3] Kielstra DP. Talent Managemrnt - A Strategic Actor. 2016.

[4] ACCA. The 12 Tenets of Tax. 2011. p. 4-7.

[5] Mulyadi MS, Anwar Y, Kisma EBAD. Examining corporate governance and corporate tax management. International Journal of Finance \& Banking Studies. 2014;3(3):47.

[6] PWC. IFRS 16: The leases standard is changing Are you ready? 2016(February).

[7] PWC. The new lease standard, IFRS 16 Leases. 2016(April):104-.

[8] Akbulut DH. The Effect of Operating Leases Capitalization on FinancialStatements and Accounting Ratios: A Literature Survey. Economics and Management, Eurasian Studies in Business and Economic. 2017;7.

[9] Kostolansky J, Stanko B. The joint FASB/IASB Lease Project : Discussion And Industry Implications. Journal of Business \& Economics Research. 2011;9(9):29-35.

[10] Wong K, Joshi M. The Impact of Lease Capitalisation on Financial Statements and Key Ratios: Evidence from Australia. Australasian Accounting, Business and Finance Journal. 2015;9(3):27-44.

[11] Eberhartinger E, Klostermann M. What if IFRS were a Tax Base? New Empirical Evidence from an Austrian Perspective. Accounting in Europe. 2007;4(2):141-68.

[12] McKinsey Global I. The archipelago economy : Unleashing Indonesia's potential. 2012. p. 7-65.

[13] OECD/IEA. Quantifying Principal-Agent Problens in Energy Efficiency2007.

[14] Hejazi FA, Ramanathan RA, Jaffar MS. Seismic Response of a Light Rail Transit Station Equipped with Braced Viscous Damper. Science \& Technology. 2016;24(2):273-83.

[15] Husin NI, Ahmad AC, Wahid AMA, Kamaruzzaman SN. Energy Efficiency Criteria for Green Highway. Social Science \& Humanities. 2017;25:119-28. 
[16] McWilliams JA, Walker IS. Home Energy Article : A Systems Approach to Retrofitting Residential HVAC Systems. Lawrence Berkeley National Laboratory. 2005.

[17] International Energy A. 2013 Annual Report. 2013

[18] Kumbaroglu G, Madlener R. Evaluation of economically optimal retrofit investment options for energy savings in buildings. Energy and Buildings. 2012;49:327-34.

[19] Mearig T, Coffee N, Morgan M. Life Cycle Cost Analysis Handbook1999.

[20] Almeida AM, Bassols A, Bendixen E, Bhide M, Ceciliani F, Cristobal S, et al. Animal board invited review: advances in proteomics for animal and food sciences. Animal. 2015;9(01):1-17.

[21] Bennich P. Test Report - Clear, Non-Directional LED Lamps. 2015.

[22] Polzin F, von Flotow P, Nolden C. Modes of governance for municipal energy efficiency services ??? The case of LED street lighting in Germany. Journal of Cleaner Production. 2016;139:13345 .

[23] Singh A. A restaurant case study of lease accounting impacts of proposed changes in lease accounting rules. International Journal of Contemporary hospitality Management. 2011;23(6):820-39.

[24] The I. At a glance - IFRS 16 Leases. 2016.

[25] Mellado L, Parte L. Determinants of corporate lobbying intensity in the lease standard-setting process. Revista de Contabilidad. 2016(xx):1-12.

[26] Holthausen RW, Leftwich RW. The economic consequences of accounting choice implications of costly contracting and monitoring. Journal of Accounting and Economics. 1983;5(C):77117.

[27] Navigant Consulting I. Green Leases Toolkit. The California Sustainability Alliance Program. 2017.

[28] Watts RL, Zimmerman JL. Positive Accounting Theory: A Ten Year Perspective. The Accounting Review. 1990;65(1).

[29] Duke JC, Hsieh SJ, Su Y. Operating and synthetic leases: Exploiting financial benefits in the post-Enron era. Advances in Accounting. 2009;25(1):28-39.

[30] Cornaggia KJ, Franzen LA, Simin TT. Bringing leased assets onto the balance sheet. Journal of Corporate Finance. 2013;22(1):34560.

[31] Schallheim J, Wells K, Whitby RJ. Do leases expand debt capacity? Journal of Corporate Finance. 2013;23:368-81.

[32] Krische SD, Sanders PR, Smith SD. Lease transaction structuring, earnings management, and management credibility. Research in Accounting Regulation. 2012;24(1):33-9.

[33] Deviarti HSEMBA, Kurniawati HSEAM, Sun YSEMB, W HSDMMABKP. The Convergency of IFRS in Indonesia Accounting Standard : Do Vocational Schools Need To Change Their Curriculum ? International Journal of Information Technology and Business Management. 2012;2(1).

[34] Siregar SV, Djakman CD, Maharani A, Farahmita A, Ningrum AS Financial Instruments Disclosure : Comparison of Indonesian and UK Banks. International Journal of Finance and Accounting. 2016;5(1):62-6.

[35] Hamidah. Adoption of International Financial Reporting Standards (IFRS) in Indonesia. Journal of Economics, Business, and Accountancy Ventura. 2013;16(2):355-72.

[36] Ikatan Akuntan I. Sewa - Draft Eksposur PSAK No. 73. 2017.

[37] Ikatan Akuntan I. Sewa Operasi - Insentif - ED ISAK No. 23. 2011.

[38] Ikatan Akuntan I. Evaluasi Substansi Beberapa Transaksi Yang Melibatkan Suatu entuk Legal Sewa - ED ISAK No. 24. 2011

[39] Ikantan Akuntan I. Interpretasi Standar Akuntansi Keuangan Hak atas Tanah - ED ISAK No. 25. 2011.

[40] Ikatan Akuntan I. Pernyataan Standar Akuntansi Keuangan Tentang Sewa - PSAK No. 30. 2014.

[41] Hoogervorst $\mathrm{H}$, editor The imprecise world of accounting2012.

[42] Cahyonowati N. Model Moral dan Kepatuhan Perpajakan: Wajib Pajak Orang pribadi. Jaai. 2011;15(Desember):161-77.

[43] Sumartaya D, Hafidiah A. The Influence Of Taxpayer's Awareness And Tax Morale Toward Tax Evasion. International Journal of Business, Economics and Law. 2014;5(1):9-.

[44] Parlaungan G. The Tax Morale of the Individual Taxpayers in Indonesia by Demographic Factors. 2014:1-10.

[45] Tatariyanto F. Taxing the Underground Economy : The Case of Indonesia. 2014;5(27):236-51.

[46] Russell B. Revenue Administration: Managing the Shadow Economy. Fiscal Affairs Department. 2010;1998(3):1-85.

[47] Corbin JM, Strauss A. Grounded theory research: Procedures, canons, and evaluative criteria. Qualitative Sociology. $1990 ; 13(1): 3-21$
[48] Glaser BG. The Future of Grounded Theory. Qualitative Health Research. 1999;9(6):836-45.

[49] Glaser BG. Grounded Description : No No. 2016;15(2):3-7.

[50] Latham J. Conceptual Framework. 2012. p. 1-6.

[51] Tomkins C, Groves R. The everyday accountant and researching his reality. Accounting, Organizations and Society. 1983;8(4):36174.

[52] United States Environmental Protection A. Business Analysis For Energy-Efficiency Investments. Energy Star Buildings Manual. 1998:12-.

[53] Laitner JaS, Nadel S, Elliott RN, Sachs H, Khan aS. The LongTerm Energy Efficiency Potential : What the Evidence Suggests. 2012(January):1-88. 